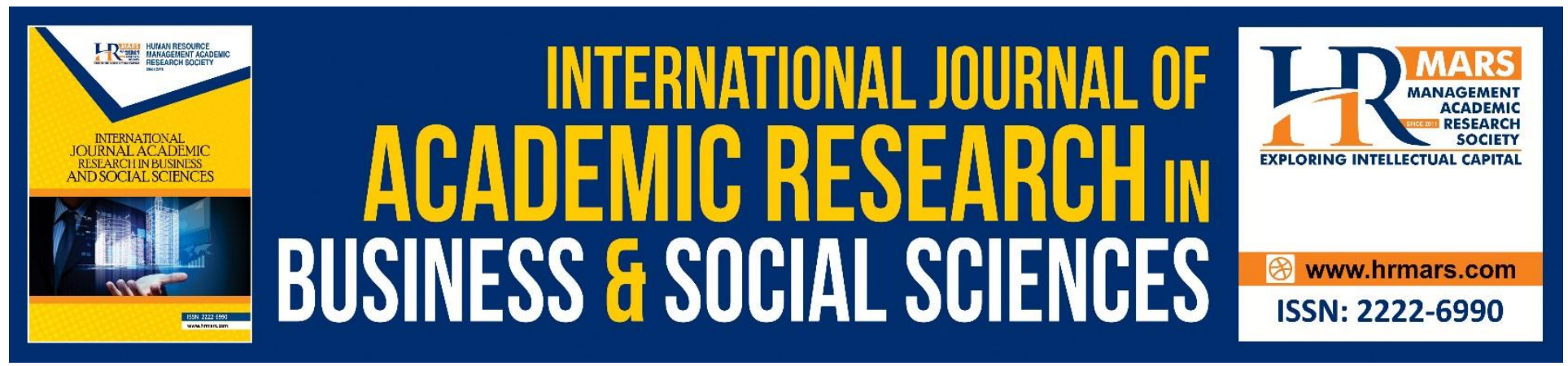

\title{
Determinant of Sustainability Consumers Purchase Decision for Green Product
}

Siti Norbaya Yahaya, Mira Shafiqa Samsuri, Nor Azah Binti Abdul Aziz

To Link this Article: http://dx.doi.org/10.6007/IJARBSS/v8-i10/5298 DOI: $10.6007 /$ IJARBSS/v8-i10/5298

Received: 18 Sept 2018, Revised: 26 Oct 2018, Accepted: 28 Oct 2018

Published Online: 06 Nov 2018

In-Text Citation: (Yahaya, Samsuri, \& Aziz, 2018)

To Cite this Article: Yahaya, S. N., Samsuri, M. S., \& Aziz, N. A. B. A. (2018). Determinant of Sustainability Consumers Purchase Decision for Green Product. International Journal of Academic Research in Business and Social Sciences, 8(10), 1279-1286.

Copyright: (C) 2018 The Author(s)

Published by Human Resource Management Academic Research Society (www.hrmars.com)

This article is published under the Creative Commons Attribution (CC BY 4.0) license. Anyone may reproduce, distribute, translate and create derivative works of this article (for both commercial and non-commercial purposes), subject to full attribution to the original publication and authors. The full terms of this license may be seen

at: http://creativecommons.org/licences/by/4.0/legalcode

Vol. 8, No. 10, 2018, Pg. 1279 - 1286

http://hrmars.com/index.php/pages/detail/IJARBSS

JOURNAL HOMEPAGE

Full Terms \& Conditions of access and use can be found at http://hrmars.com/index.php/pages/detail/publication-ethics 


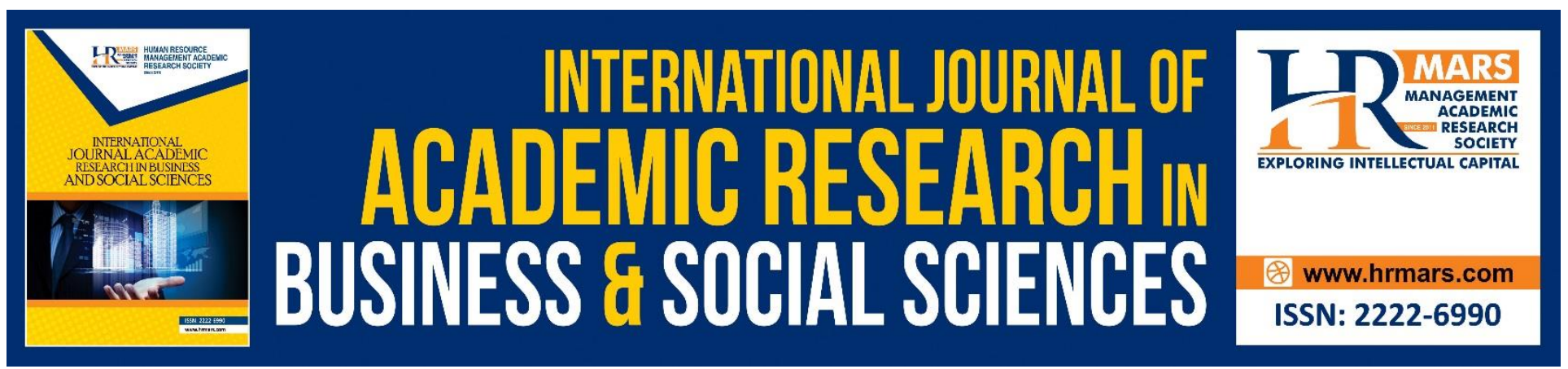

\title{
Determinant of Sustainability Consumers Purchase Decision for Green Product
}

\author{
Siti Norbaya Yahaya, Mira Shafiqa Samsuri, Nor Azah Binti Abdul \\ Aziz
}

Faculty of Technology Management and Technopreneurship, Universiti Teknikal Malaysia Melaka

\begin{abstract}
Sustainability has become a major element of environmental stability in which it affects the situation of future generations in Malaysia. Today going green concept is one of the main goals in Malaysia. Government plays a vital role in delivering information and conducts several campaigns to inform customers about the benefits of choosing green products. Unfortunately, there is still a gap between an environmentally friendly deal and a consumer decision to purchase green products. This study is conducted to identify the consumer factors of purchase decision of green products in Malaysia. There are 300 respondents involved in this study distributed to all consumers throughout Malaysia using structured questionnaires to investigate the relationship between factors that influence the purchase decision of green product. This study considering demographic, economic and awareness and knowledge as three variables contribute to the purchase decision for green product. This study will mainly adopt the quantitative approach in data analysis. The data is analyzed using STATA software. Statistical analysis is employed to analyze the accuracy of the finding the relationship among variables. In order to get more in depth discussion, regression analysis is employed in this study.
\end{abstract}

Keywords: Eco-Friendly, Consumer Buying Decision, Factors, Environment.

\section{Introduction}

Malaysia is categorized under developing country whereby considering many sectors are rising up even though the economic growth was slowly increasing. Based on Malaysian Institute of Economic Research (MIER), Malaysia's economy performed better than expected in the first half of 2017 (1H2017). Real GDP grew by 5.6\% year-on-year basis and further expanded to $5.8 \%$ in the second quarter. However the growth of economy does not bring along the sustainable criteria as discussed widely from different perspective by different experts. Discussion on environmental stand seems to be ignored without government assistance and government intervention. Environmental problem affect ecosystems and all living creatures in Malaysia is one of the bad results from the growth economy. Concerns about environment in this era has strongly attract researcher to study the impact of over consumption of natural resources. 
INTERNATIONAL JOURNAL OF ACADEMIC RESEARCH IN BUSINESS AND SOCIAL SCIENCES

Vol. 8, No. 10, Oct. 2018, E-ISSN: 2222-6990 @ 2018 HRMARS

This phenomenon makes people think about the future and condition of their next generation. Therefore environmental awareness by consumers is rise up and they started to talk about going green. Numerous organization in Malaysia are started to think of bringing out green product to market. Where the worries regarding the natural environment in general have made companies as well as consumers to try to reduce the damages imposed to the natural environment (Hamzaoui Essoussi \& Linton, 2010). Since consumers are already alert about environmental awareness, some companies involve in socio economics need to include green element towards their product because consumer and environment was engaged. This is one the ways of marketing communication toward consumer. The companies need to develop new mentality of business despite not only think about the profit, but they must meet the consumers' need and want which solve the social problems where this directs to consumer behavior (Boztepel, 2012).

\section{Literature Review}

Nowadays people start to aware about green product yet still few of consumers are still consider to buy green product as they are more preferable to have the conventional one where easily to get and more affordable to buy. Even though lot of researcher on green marketing established, the consumer behavior to buy green product still not deeply understood enough. From the past research consumers still lack of real understanding mainly when green products are sold at higher price (Matthews 2017). Consumers do express firmly worries and aware about environment, but their behavior are not in conjunction with the issue. Consumer behavior of the actual purchasing behavior exists as lack of information about green product; in addition it caused limited movement of market share of green product (Ohtomo \& Hirose, 2007). Although consumer acknowledge about benefit of green product towards surrounding and future yet still not all willing to pay for eco-friendly product because certain green product are more likely high in prices and hard to get in nearest store. Therefore this studies closing the gap in bringing more effective information to producer in changing the consumer taste and production trend. Other than that, this study will furnish the information on consumer behavior in developing a tendency to not only intent to purchase but those who already consume the green product will intend to repeat or repurchased the product again in the future.

Green product by definition is a product consume by no effect or no harm to environmental stand. A better guideline to purchase eco-label product is by looking the certification labeling. According to Ecolabel Index (2017) there is several of eco-label available in Malaysia such as Audubon International, Global Organic Textile Standard, and SIRIM Certified. One of the factor contribute the intention of purchase decision of green product is consumer economics level. Nowadays consumer with established economies are willing to pay for product which give benefit to them on short or long term. Previous study proved the higher number of consumer to pay the highest price for alternative product with environmental certificate (Laroche, Bergeron, \& Barbaro-Forleo,2001). According to Stefanie Van Durme (2012) in How Cool Brand Stay Hot, the youth in Malaysia are more willing to pay for eco-friendly product as long as the product is reliable. Second factor considered in this study is demographic factor. Kotler and Armstrong (2014) define demography is the study of human population in terms of location, age, gender, race and other statistics. Few studies conclude that large numbers of women linked toward environment and more favorable toward environment issues (Aysel Boztepel 2012). Not being left behind is married couples. According to Aysel Boztepel, (2012) 
clarifies that marital status is the factor on consumer buying decision on green product which result of his research show that only unmarried consumers affected on green promotion while for married couple whose either have children or not, they only affected on green price of eco-friendly product.

Third factor included consumer knowledge and awareness toward purchase and repurchase decision of green product. Environmental awareness is one of motivation for buying eco-friendly product (Wee 2014). It can be defined that environmental awareness is an ecologist who hold firmly self-efficacy towards environmental from being contaminated with harmful substances as a consequence of human activities and sense of duty with honor to future usage of resources (Aysel Boztepe 2012). Whereby from other study various consumers buying behavior were influence by several elements such as knowledge of the effect of environment sustainability (Matthews 2017).

There are several models, which use as for understanding the Pro-environment Behavior (PEB). The second model of ecological behavior, which have fewer gaps than the first model of ecological behavior that is linear progression models. Altruism, empathy and pro-social behavior models are attributes in second model of ecological behavior.

\section{Methodology}

In this research the most appropriate studies can be utilized is using descriptive analysis. Methodological choice for this research is conducted by using the quantitative method research. Primary data are the information directly assembled by the researcher through questionnaires. In addition there are also numerous data taken from secondary data for the statistic has been gathered from other research. Cronbach's alpha is use as to measure the consistency of responses. The reliability is tested in pilot test and real research. The study used pilot test in order to test the validity. Non-probability sampling and convenience sampling techniques are applied to the targeted respondent. Meanwhile for the number of sample size taken is 384 . The study used Pearson Correlation, Simple Linear Regression and Multiple Regression in order to explain the statistical data. In this study, three hypothesis are tested:

Hypothesis 1:

There is a significant relationship between demographic factors towards consumer buying decision. ī'

Demography is the study of human population in terms of location, age, gender, race and other statistics (Kotler and Amstrong, 2014) These attributes are age, occupation, education level, material status and living location.

Hypothesis 2:

There is a significant relationship between economic factors towards consumer buying decision. One of the factors that affect consumers' response about eco-friendly products is a price and quality of the product, which might have strong influence and prediction sustainable to the consumption behavior.

Hypothesis 3:

There is a significant relationship between knowledge and awareness factors towards consumer buying decision.

Environmental awareness is one of motivation for buying eco-friendly product (Wee et al, 2014). Whereby from other study many consumers buying behavior were influence by many elements such 
INTERNATIONAL JOURNAL OF ACADEMIC RESEARCH IN BUSINESS AND SOCIAL SCIENCES

Vol. 8, No. 10, Oct. 2018, E-ISSN: $2222-6990$ ㄷ 2018 HRMARS

as knowledge of the effect of environment sustainability [8].

Figure 1: Research Framework

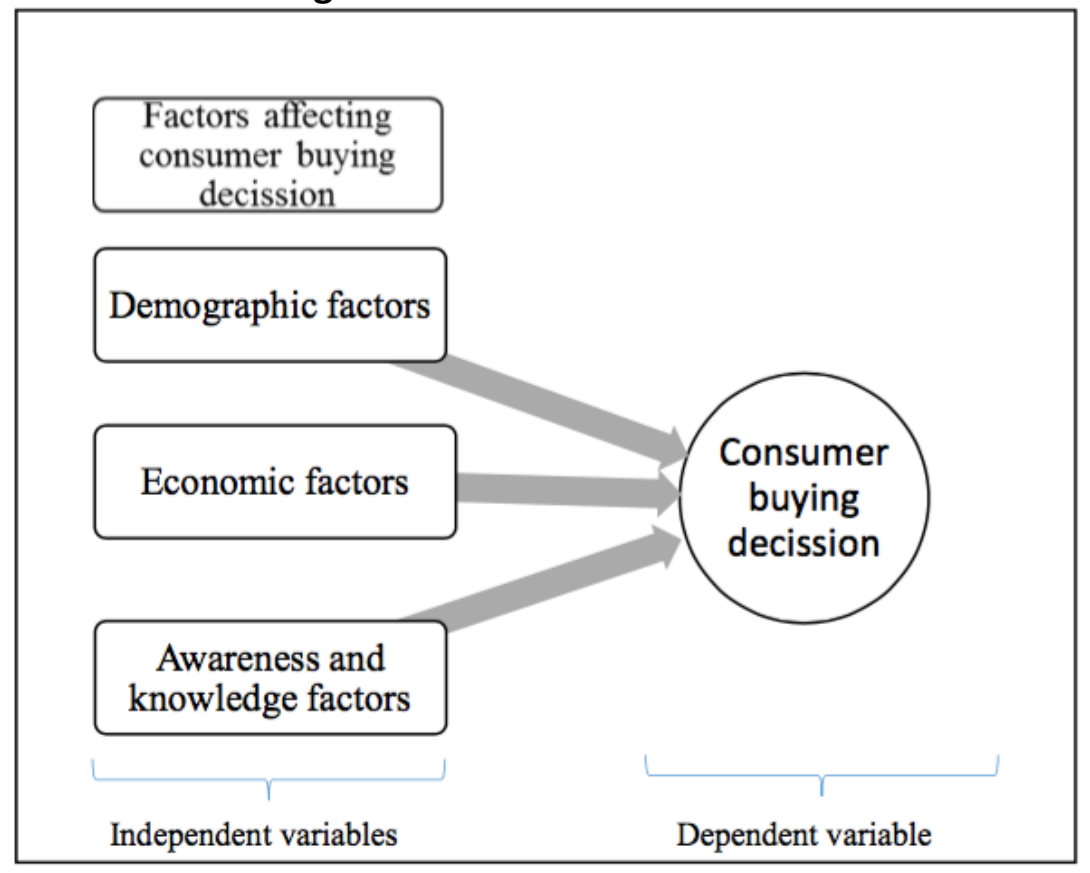

\section{Results and Discussion}

The result shows $p=0.000$ for demographic which indicates that demographic factor affect the consumer buying decision toward eco-friendly product. Thus, the null hypothesis ( $\mathrm{HO}$ ) has been rejected while alternative hypothesis $(\mathrm{H} 1)$ is accepted. This can be supported by past study that female which one of sub variable of demographic in this study are more affected to pay for ecofriendly product [9]. Demographic (gender, age, education, marital status, children and income) have significant relationship with consumer buying decision (Fisher et al, 2014). For economic $p$ value is 0.000 which indicates that economic factor does affect the consumer buying decision toward ecofriendly product. According to the past research stated in finding result where economic (price) is influence towards consumer buying decision (Yoshi and Rahman,2015). This fact can be supported by similar research where economic (price) is the strongest factors affect the willingness of the consumer to pay for eco-friendly product $($ Suki,2013). The knowledge and awareness shows $p$ value is 0.000 which indicates that knowledge and awareness factor does affect the consumer buying decision toward eco-friendly product. This can be supported through past research which claimed in their study that consumer who have high level of environmentally consciousness are more affected to purchase eco-friendly products (Kumar and Ghodeswar, 2015) Furthermore, researcher have confirmed that consumer who have high environmental concern or any motivation towards environment are more consider to buy eco-friendly product (Yoshi and Rahman , 2015).

Objective 1: To identify the factors of consumer buying decision towards eco-friendly products. 
INTERNATIONAL JOURNAL OF ACADEMIC RESEARCH IN BUSINESS AND SOCIAL SCIENCES

Vol. 8, No. 10, Oct. 2018, E-ISSN: 222 2-6990 @ 2018 HRMARS

Figure 2 : $p$-value of the variable

\begin{tabular}{cc}
\hline IV & p-value \\
\hline Demographic & 0.000 \\
Economic & 0.000 \\
Knowledge & 0.000
\end{tabular}

Objective 2: To analyze the relationship between factors of consumer buying decision towards willingness to pay for eco-friendly products.

Figure 3 : The Pearson correlation matrix for dependent variables and explanatory variables

\begin{tabular}{|c|c|c|c|c|c|}
\hline & & Demographic & Economic & $\begin{array}{l}\text { Knowledge } \\
\text { and } \\
\text { Awareness }\end{array}$ & $\begin{array}{l}\text { Consumer } \\
\text { Buying } \\
\text { Decission }\end{array}$ \\
\hline \multirow{2}{*}{ Demographic } & Pearson Correlation & 1 & .047 & $.184^{* *}$ & $.222^{* *}$ \\
\hline & Sig. (2-tailed) & & .361 & .000 & .000 \\
\hline \multirow{2}{*}{ Economic } & Pearson Correlation & .047 & 1 & -.019 & $.490^{* *}$ \\
\hline & Sig. (2-tailed) & .361 & & .711 & .000 \\
\hline \multirow{2}{*}{$\begin{array}{l}\text { Knowledge and } \\
\text { Awareness }\end{array}$} & Pearson Correlation & $.184^{* *}$ & -.019 & 1 & $.482^{\star \star *}$ \\
\hline & Sig. (2-tailed) & .000 & .711 & & .000 \\
\hline \multirow{2}{*}{$\begin{array}{l}\text { Consumer Buying } \\
\text { Decission }\end{array}$} & Pearson Correlation & $.222^{* *}$ & $.490^{* *}$ & $.482^{* * *}$ & 1 \\
\hline & Sig. (2-tailed) & .000 & .000 & .000 & \\
\hline
\end{tabular}

The calculated value for demographic by the Pearson's correlation value is 0.222 which indicates that demographic correlated to consumer buying decision, in which very weak relationship with consumer buying decision. Next, Pearson's correlation value for economic is 0.490 which indicates that economic correlated to consumer buying decision, in which moderate relationship with consumer buying decision. Lastly, Pearson's correlation value for knowledge and awareness is 0.482 , which indicates that knowledge and awareness correlated to consumer buying decision, in which moderate relationship with consumer buying decision.

Objective 3: To investigate the most significant factor that affect consumer buying decision towards eco-friendly products 
INTERNATIONAL JOURNAL OF ACADEMIC RESEARCH IN BUSINESS AND SOCIAL SCIENCES Vol. 8, No. 10, Oct. 2018, E-ISSN: 222 2-6990 @ 2018 HRMARS

Figure 4: ANOVA

\begin{tabular}{|c|c|c|c|c|}
\hline Model & $R$ & R Square & Adjusted R Square & $\begin{array}{c}\text { Std. Error of the } \\
\text { Estimate }\end{array}$ \\
\hline 1 & $.703^{\mathrm{a}}$ & .494 & .490 & .27124 \\
\hline \multicolumn{2}{|c|}{ a. Predictors: (Constant), Knowledge_and_Awareness, Economic, Demographic } \\
\hline
\end{tabular}

Figure 4 shows the ANOVA table, which assessed to compare to only the intercept with the significance of the overall model. Giving an F-test result for the model. This almost significant, even if only a small amount of variance is explained by the model. Significance value based on Figure 4 is 0.000 which less than 0.001 . Thus the significance variable of the overall model is $F(3,380)=123.673$, $\mathrm{p}<0.001$. However it only counted $49.4 \%$ variability to support consumer buying decision.

Figure 5: Coefficient

\begin{tabular}{|c|c|c|c|c|c|c|}
\hline & \multirow[t]{2}{*}{ Model } & \multicolumn{2}{|c|}{$\begin{array}{c}\text { Unstandardized } \\
\text { Coefficients }\end{array}$} & \multirow{2}{*}{\begin{tabular}{|c|} 
Standardized \\
Coefficients \\
Beta \\
\end{tabular}} & \multirow[t]{2}{*}{$\mathrm{t}$} & \multirow[t]{2}{*}{ Sig. } \\
\hline & & B & Std. Error & & & \\
\hline \multirow{4}{*}{1} & (Constant) & 1.333 & . 169 & & 7.910 & .000 \\
\hline & Demographic & .091 & .030 & .112 & 3.005 & .003 \\
\hline & Economic & .284 & .021 & .494 & 13.510 & .000 \\
\hline & Knowledge_and_Awareness & .305 & .024 & .471 & 12.687 & .000 \\
\hline
\end{tabular}

Economic is the strongest predictors, $\beta=0.494, \mathrm{t}(384)=13.510, \mathrm{p}<0.05$, showing the economic factors most affecting factors in consumer buying decision. Knowledge and awareness the moderate predictors as $\beta=0.471, t(384)=12.687, p<0.05$, showing the knowledge and awareness is the second highest factor which affecting the consumer buying decision. Meanwhile demographic is the lowest independent contribution to consumer buying decision as $\beta=0.112, \mathrm{t}(384)=3.005$, $p<0.05$. Therefore the most significant factor is economic factor.

\section{Conclusion}

The results clearly showed that all independent variables (demographics, economic and knowledge and awareness) led to significant influence on the dependent variable (consumer buying decision). In addition, the results for hypothesis testing also showed that there is a significant relationship between all independent variables and dependent variable in purchasing eco-friendly product. Next from this research can conclude there is a moderate level of relationship between each independent variables and dependent variable in purchasing eco-friendly product. Lastly from data calculated can be concluded that demographic (V1) is the lowest significant to consumer buying decision (Y), meanwhile knowledge and awareness (V3) are the moderate significant for consumer buying decision (Y), while the economic (V2) lead to be the most significant factor that affecting consumer buying decision $(\mathrm{Y})$ compared to other two variables. From this research there is not only three factors are affecting the consumer buying decision. There also have big number of percentage of others factors that affecting consumer buying decision. 
INTERNATIONAL JOURNAL OF ACADEMIC RESEARCH IN BUSINESS AND SOCIAL SCIENCES

Vol. 8, No. 10, Oct. 2018, E-ISSN: 2222-6990 ㄷ 2018 HRMARS

\section{Acknowledgement}

I would like to take this opportunity to express my gratitude to Universiti Teknikal Malaysia Melaka for supporting this research.

\section{References}

[1] Biswas, A., \& Roy, M. (2015). Green Products: An Exploratory Study On The Consumer Behaviour In Emerging Economies Of The East. Journal Of Cleaner Production, 87, 463-468.

[1] Boztepe, A. (2012). Green marketing and its impact on consumer buying behavior. European Journal of Economic \& Political Studies, 5(1).

[3] Fisher,C., Bashyal, S. And Bachman, B.(2012).Demographic Impacts On Environmentally Friendly Purchase Behaviors. Journal Of Targeting, Measurement And Analysis For Marketing, 20(3-4), Pp.172184

[4] Hamzaoui Essoussi, L., \& Linton, J. D. (2010). New or recycled products: how much are consumers willing to pay?. Journal of Consumer Marketing, 27(5), 458- 468.

[5] Joshi,Y.Andrahman,Z.(2015).Factors Affecting Green Purchase Behaviour And Future Research Directions. International Strategic Management Review, 3(1-2), Pp.128-143.

[6] Kotler, P., \& Armstrong, G. (2014). Principles Of Marketing. Pearson Education.

[7] Kumar,P. And Ghodeswar, B.(2015).Factors Affecting Consumers' Green Product Purchase Decisions. Marketing Intelligence \& Planning, 33(3), Pp.330-347

[8] Laroche, M., Bergeron, J., \& Barbaro-Forleo, G. (2001). Targeting Consumers Who Are Willing To Pay More For Environmentally Friendly Products. Journal Of Consumer Marketing, 18(6), 503-520.

[9] Mohd Suki, N. (2013). Green Awareness Effects On Consumer S' Purchasing Decision: Some Insights From Malaysia. IJAPS, [Online] Vol. 9(No. 2).

[10] Meyer, A. (2001). What's In It For The Customers? Successfully Marketing Green Clothes. Business Strategy And The Environment, 10(5), 317-330.

[11] Matthews, D. (2017). Consumer Decision Making When Purchasing Eco-Friendly Apparel. International Journal Of Retail \& Distribution Management, 45(4), 404-418.

[12] Ohtomo, S., \& Hirose, Y. (2007). The dual-process of reactive and intentional decision-making involved in eco-friendly behavior. Journal of Environmental Psychology, 27(2), 117-125.

[13] Tung,T.,F.Koenig,H.andChen,H.(2017).Effects of Green Self-Identity and Cognitive and Affective Involvement on Patronage Intention in Eco-Friendly Apparel Consumption: A

[14] Wee, C. S., Ariff, M. S. B. M., Zakuan, N., Tajudin, M. N. M., Ismail, K., \& Ishak, N. (2014). Consumers Perception, Purchase Intention And Actual Purchase Behavior Of Organic Food Products. Review Of Integrative Business And Economics Research, 3(2), 378. 